\title{
Study on Wave Energy Conversion by Using Oscillating Water Column in Alindau Waters
}

\author{
Setiyawan $^{1 *}$, Erwin Affandi ${ }^{1}$ and Lisa Arnita Anzar ${ }^{1}$ \\ ${ }^{1}$ Civil Engineering Department, Tadulako University, Palu, Indonesia
}

\begin{abstract}
Growth electricity consumption in central sulawesi encourages increased utilization of conventional resources such as petroleum products and coal as alternative energy plant. It causes some adverse effect either on the environment, health and economy. As a result, the alternative of conversion energy from non-conventional resources must be provided. Central Sulawesi with coastline about $4,013 \mathrm{~km}$ has immense potential in developing wave energy as an alternative of Renewable Energy Resource. This paper investigated the potential for wave energy conversion in Lindau Water as an alternative of power plant by using Oscillating Water Column System (OWC). The value of significant wave height and periods are calculated based on the Wilson method, which is then analysed to determine the potential of electricity that feasible converted from wave energy in Lindau waters and potential to applicated wave energy conversion using OWC in Lindau Waters. The result found the conversion of Lindau waters wave energy produce the largest power that can be converted is about 21.000 watts. Its shows the potential that can be applied to coverage the need electricity by using wave energy in Alindau Village.
\end{abstract}

\section{1 introduction}

Fulfilment of electrical energy is a concern for the government because the influence of population growth greatly affects for the supplying of electricity needs in the community. The increasing population, the greater the responsibility for the government in supplying electricity needs. Alindau is one of the villages in Donggala Regency which has a friendly and kind population and is open to efforts to make power plants. Not only strategic but also has a wave that is high enough to be used as a reference that the waters in our opinion are feasible in the study of Ocean Wave Power Plants.

In 2000 the world's first commercial Wave Power Device, the Islay LIMPET was installed on the coast of Islay in Scotland and connected to the National Grid [1].

This device floats on the surface of the water, held in place by cables connected to the seabed. The point-absorber is defined as having a device width much smaller than the incoming wavelength $\lambda$. A good point absorber has the same characteristics as a good wave-

\footnotetext{
* Corresponding author: setiyawanvip@yahoo.co.id
} 
maker. The wave energy is absorbed by radiating a wave with destructive interference to the incoming waves. Buoys use the rise and fall of swells to generate electricity in various ways including directly via linear generators [2], or via generators driven by mechanical linear-torotary converters [3] or hydraulic pumps [4].

Once the wave energy is captured at a wave source, power must be carried to the point of use or to a connection to the electrical grid by transmission power cables [5]. Oscillating Water Column devices can be located onshore or in deeper waters offshore. With an air chamber integrated into the device, swells compress air in the chambers forcing air through an air turbine to create electricity [6]. Submerged pressure differential-based converters are a comparatively newer technology [7] utilizing flexible (usually reinforced rubber) membranes to extract wave energy. The Tethys database provides access to scientific literature and general information on the potential environmental effects of wave energy [8]. WECs have gone under heavy examination through research, especially relating to their efficiencies and the transport of the energy they generate. NREL has shown that these WECs can have efficiencies near 50\% [9]. This is a phenomenal efficiency rating among renewable energy production. For comparison, efficiencies above $10 \%$ in solar panels are considered viable for sustainable energy production [10]. Even further research has led to development of smaller, compact versions of current WECs that could produce the same amount of energy while using roughly one-half of the area necessary as current devices [11]. Furthermore, supporting infrastructure, such as offshore grid connections, is not widely available [12]. Offshore deployments of WECs and underwater substations undergo complicated procedures, which can put excessive stress in companies working in these applications. In 2019, for example, the Swedish production subsidiary Sea based Industries AB was liquidated due to "extensive challenges in recent years, both practical and financial" [13]. A group of wave energy devices deployed in the same location is called wave farm, wave power farm or wave energy park. Wave farms represent a solution to achieve larger electricity production. The devices of a park are going to interact with each other hydrodynamically and electrically, according to the number of machines, the distance among them, the geometric layout, the wave climate, the local geometry, the control strategies. The design process of a wave energy farm is a multi-optimization problem with the aim to get a high-power production and low costs and power fluctuations [14]. A 2017 study by Strathclyde University and Imperial College focused on the failure to develop "market ready" wave energy devices - despite a UK government push of over $£ 200$ million in the preceding 15 years - and how to improve the effectiveness of future government support [15].

Basically, the ocean wave principle in a power plant is how to make this turbine generator can stir the generator. Thus, we have to choose a strategic place that can be used to this power plant research. Although research to get optimal technology in ocean wave energy content is still being improved, but the government also provides opportunities for the community to make best use of this natural Indonesia to be used as a source of livelihood as mentioned in 4th paragraph of constitution. And in this case, we chose an alternative that can convert ocean waves into electrical energy an oscillating water column system or commonly called Oscillating Water Column (OWC).

Rooted from this problem the authors took the topic "Study of the Potential of Ocean Wave Power Plants Using Oscillating Water Column (OWC) Systems in Alindau Waters" as the subject of research.

Ocean waves can be defined as the shape of the sea surface peak of waves and valley waves by oscillatory movements due to winds, volcanic eruptions, ocean floor erosion, or ship traffic ocean waves have dimensions namely wave period, wavelength, wave height, and wave velocity. The most widely used waves in the planning of civil engineering are wind waves and tidal waves. Wind waves, hereinafter referred to as waves, which come to the beach, can cause currents that cause the movement of coastal sediments, either moving in a 
perpendicular direction to the coastline, or moving in a direction parallel to the coastline. This sediment movement can change the shape and position of the coastline from its original shape and position.

\section{Research location}

This project is located at $0^{\circ} 21^{\prime} 17.90$ "S and $119^{\circ} 45^{\prime} 31.62^{\prime \prime} \mathrm{E}$ in Alindau Village, Donggala Regency, Central Sulawesi Province, is $\pm 61 \mathrm{~km}$ from Palu City to the North towards the City of Toli-toli and the research location is directly on the coastline. Electricity supply in this area comes from a neighbouring village, Oti Village. Based on the topography, Alindau Village has the characteristics of a diverse region, among others located at sea level between 100 meters above sea level. The type of climate in Alindau Village is a tropical climate with an average temperature of $28^{\circ} \mathrm{C}$, while the maximum temperature can reach $28^{\circ} \mathrm{C}$. The climate in Alindau Village, as with other regions in Sindue Tobata District, Alindau Village has two seasons, namely the rainy and summer seasons. The rainy season occurs in OctoberMarch and summer occurs in April-September.

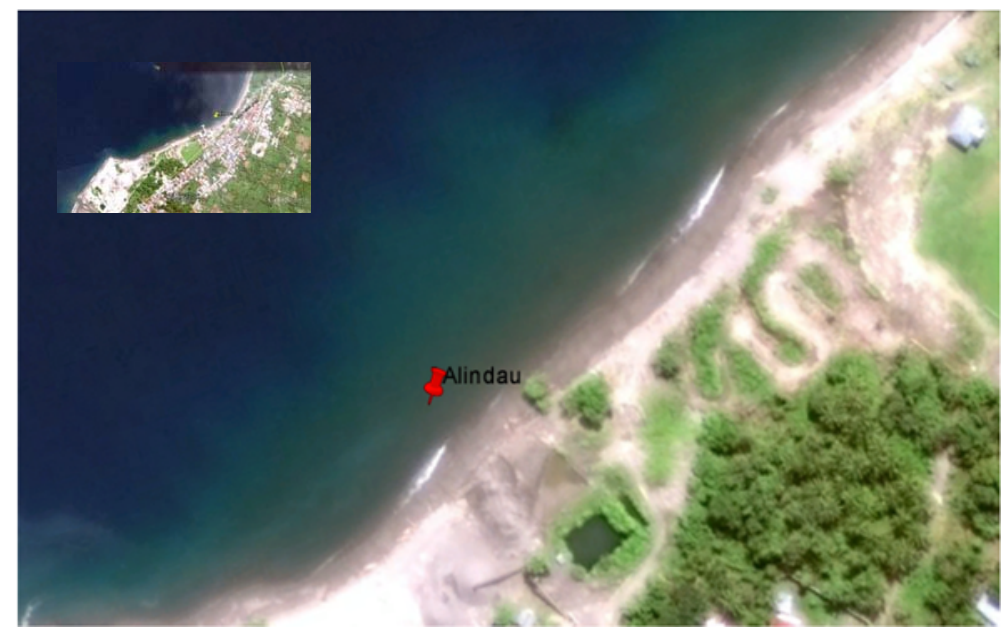

Fig. 1. Research location

The electric energy source of the Oti Village is under the auspices of the Donggala District Government. Located in Sindue District. The power plant in Oti Village has a capacity of 5 MW. Each product uses 500 Liters of Solar per Month. Alindau waters have a long coastline of the North side around $7 \mathrm{~km}$, the length of the South coastline is about $8 \mathrm{~km}$ and an area of about $70 \mathrm{~km}^{2}$. The maximum depth of Alindau waters is $-500 \mathrm{~m}$ in the middle of the sea, and around $300 \mathrm{~m}-700 \mathrm{~m}$ from the coastline the sea depth reaches $-37 \mathrm{~m}$ to $-50 \mathrm{~m}$.

\section{Methodology}

\subsection{Ocean waves}

Ocean waves have potential and kinetic energy that can be calculated by Kim Neilsen Equation. By using the equation, it can be obtained how much energy is contained in the 
wave. The ocean wave utilization system can use air pressure from a watertight room to drive the turbine which later the turbine movement is used to produce electrical energy. This watertight room is installed fixed with the bottom structure open to the sea. Air pressure in this waterproof room is caused by the movement of up and down from the surface of the sea wave. The wave motion in this room is the movement of compresses and the movement of decompresses that are above the water level in the room. This movement resulted in a highspeed air flow reserve. This air flow is pushed through a pipe to a turbine generator that is used to generate electricity. This system can be permanently placed on the beach or can also be placed in the middle of the sea. In systems that are placed in the middle of the sea, the electricity generated is channelled to the transmission on land using a sea cable [3].

The wave height and period that generated are affected by the wind stress $U_{A}$, the length of the wind blow D and the fetch F, the length of the sea surface when the wind blows.

To find out the direction and speed of the wind, especially calculating wind tension with equation (1)

$$
U_{A}=0,17 \times U^{1,23}
$$

where:

$U_{A}=$ wind stress $(\mathrm{m} / \mathrm{s})$

$U=$ wind speed $(\mathrm{m} / \mathrm{s})$

the resultant wind velocity $(\mathrm{m} / \mathrm{s}) \mathrm{U}$ can be obtained by the equation (2)

$$
U=\sqrt{u^{2}+v^{2}}
$$

where:

$u=$ wind speed of vector $\mathrm{x}$

$v=$ wind speed of vector $\mathrm{y}$

wind direction is an indicator of the wind movement cen be calculated with equation (3)

$$
\theta=\arctan \frac{u}{v}
$$

The distance of wave formation which is assumed to have a relatively constant speed and direction of the wind that goes ashore is called wave fetch. The wave formation length that is assumed to have a relatively constant speed and wind direction to the mainland is called fetch. The fetch length is the range of the sea bounded by islands at both ends. The fetch equation can be calculated by the equation (4).

where:

$$
F=\frac{\sum F_{1} \cos \propto_{1}}{\sum \cos \propto_{1}}
$$

$F_{i}=$ fetch length-I (m)

$\propto_{1}=$ fetch measurement -I (0)

$i=$ number of fetch measurement 


\subsection{Wave forecasting}

\subsubsection{Wave height}

Based on wind speed, wind and fetch blast as discussed before, wave forecasting is found out using the Wilson Method with the following equation (5)

where:

$$
H_{s}=\frac{0,3}{g}\left[1-\left\{1+0,004 \sqrt{\left(\frac{g F}{U^{2}}\right)}\right\}-2\right] U^{2}
$$

$H_{s}=$ significant height of ocean waves $(m)$

$U=$ wind speed $(\mathrm{m} / \mathrm{s})$

$F=$ fetch length $(m)$

$\mathrm{g}=$ earth's gravity acceleration $\left(9,81 \mathrm{~m} / \mathrm{s}^{2}\right)$

\subsubsection{Wave Period}

The period is the interval of time needed to take one wave. The period is denoted by the letter "T" and the unit is seconds. The period can be calculated using the equation (6) suggested by Kim Nielsem

where:

$$
T=3,55 \sqrt{H_{s}}
$$

$T \quad=$ wave Period

$H$ = wave height

\subsubsection{Wave Length}

Wave length is the range between one peak of a wave and another. In other words, Wavelength is the distance that must be travelled by a wave in a period, calculated with equation (7).

where:

$$
\lambda=5,12 T^{2}
$$

$\lambda=$ Wave Length (m)

$T=$ Wave Period (s)

\subsubsection{Wave Velocity}

Ocean wave velocity is needed to determine the amount of energy generated by ocean waves. Ocean wave velocity is denoted by $\mathrm{C}$ with the unit being $(\mathrm{m} / \mathrm{sec})$. Ocean wave velocity equations (8)

where:

$$
C=\lambda / T
$$

$\mathrm{C}=$ Wave Velocity $(\mathrm{m} / \mathrm{s})$ 


\subsection{Wave energy calculation using Oscillating Water Column (OWC)}

Analysed the calculation of ocean wave energy in the Prototype, there are several things that must first be known, such us the potential for ocean wave energy, chamber width $2.4 \mathrm{~m}$ (based on the existing prototype), wind specific gravity $1200 \mathrm{Kg} / \mathrm{m}^{3}$, and earth's gravity acceleration $9.81 \mathrm{~m} / \mathrm{s}^{2}$. In the study of [4] about Prototype Design of Ocean Wave Power Plants Oscillating Water Column Type at Jember Bandealit Beach stated that the equation for calculating ocean wave energy use the equation (9)

where:

$$
E=\left(P_{2}-P_{0}\right) A_{2} V_{2}
$$

$E \quad=$ OWC power (Watt)

$P_{2}=$ Orifice air pressure $(\mathrm{Pa})$

$P_{0}=$ Air pressure Outside the system $(\mathrm{Pa})$

$A_{2}=$ Air speed in orifice Column $(\mathrm{m} / \mathrm{s})$

$V_{2}=$ Column area OWC $\left(\mathrm{m}^{2}\right)$

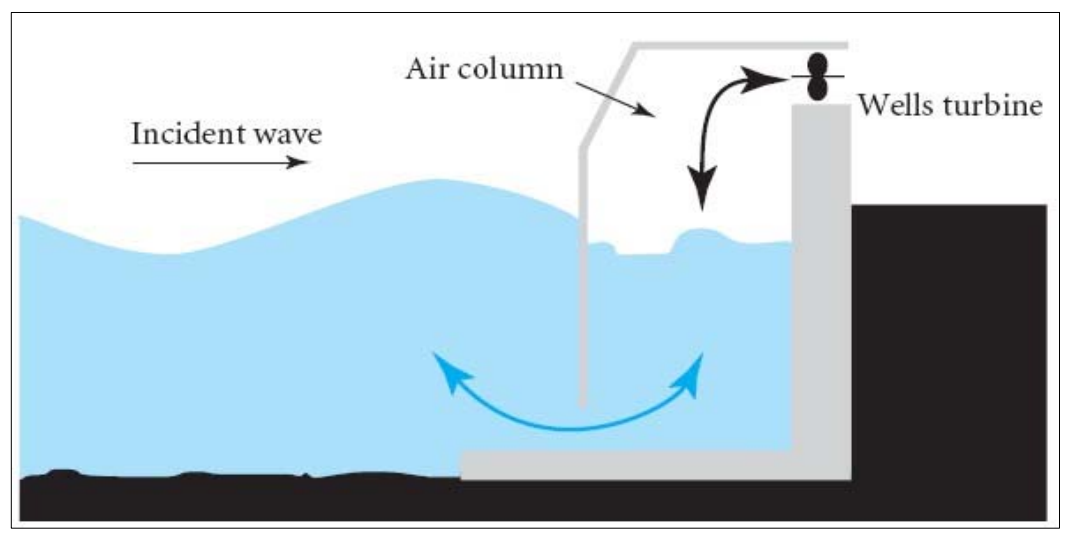

Fig. 2. Oscillating Water Column (OWC) [10]

To calculate the power, turn out of OWC using the Bernita's formula above there are certain parameters needed. Get these parameters by several phase in equation (10), (11) and (12)

1. Calculating air velocity around the column

2. Calculating airflow in Orifice

$$
V_{1}=\frac{\omega}{2} H \sin (\omega t)
$$

3. Calculating the pressure in Orifice

$$
V_{2}=\frac{A_{1}}{A_{2}} V_{1}
$$

$$
P_{2}=P_{0}+\rho\left(\frac{A_{1}}{A_{2}}\right) \frac{d \phi}{d t}+\rho \frac{Q_{2}}{A_{2}}\left(V_{2}-V_{1}\right)
$$

after calculating the discharge, the potential speed of the orifice also needs to be known by using the following equation (13) and (14)

$$
\begin{gathered}
\phi_{1} \simeq v_{1} \eta_{1}=-\frac{\omega H 2}{4} \sin (\omega t) \cos (\omega t) \\
\phi_{2} \simeq v_{1} \eta_{1}=-\left(\frac{A_{1}}{A_{2}}\right) V_{1} \frac{\omega H 2}{4} \sin (\omega t) \cos (\omega t)
\end{gathered}
$$

where:

$A_{1}=$ OWC Column Area $\left(m^{2}\right)$ 
$A_{2}=$ Orifice column area $\left(\mathrm{m}^{2}\right)$

$V_{1}=$ air flow Speed around the OWC column $(\mathrm{m} / \mathrm{s})$

$V_{2}=$ air flow Speed around the orifice $(\mathrm{m} / \mathrm{s})$

$\rho=$ specific gravity $\left(\mathrm{kg} / \mathrm{m}^{3}\right)$

$Q_{1}=$ discharge in OWC column $\left(\mathrm{m}^{3} / \mathrm{s}\right)$

$Q_{2}=$ air discharge in Orifice $\left(\mathrm{m}^{3} / \mathrm{det}\right)$

$\phi_{1,2}=$ potential speed in OWC rad.m/sec

After obtaining the wave power and output power of the OWC, the OWC Efficiency can be calculated by compare the wave power entering and leaving the column of the OWC, see equation (15)

$$
\eta \mathrm{OWC}=\frac{E}{P w} \times 100 \%
$$

To determine the electrical power generated, it is necessary to know the efficiency of a Wave Power Plant (PLTGL). The efficiency of PLTGL is obtained from equation (16)

$$
\eta \text { PLTGL }=\eta \text { OWC } \times \eta \text { generator } \times \eta \text { turbine }
$$

then the electricity generated will be calculated with equation (17)

$$
P g=P w \times \eta \text { PLTGL }
$$

to find out the power of the previous generator, must be calculated the power generated by the wave using the formula as equation (18)

where:

$$
\mathrm{PW}=0.195 \mathrm{w} \rho g h 2 \mathrm{~T}
$$

$\mathrm{Pg}=$ power of generator (watt)

$\mathrm{Pw}=$ the energy produced by the waves (watt)

\section{Result and discussion}

Wind data used is 5 years from 2012 - 2016. Then the WRPlot is processed to find out the dominant wind direction.
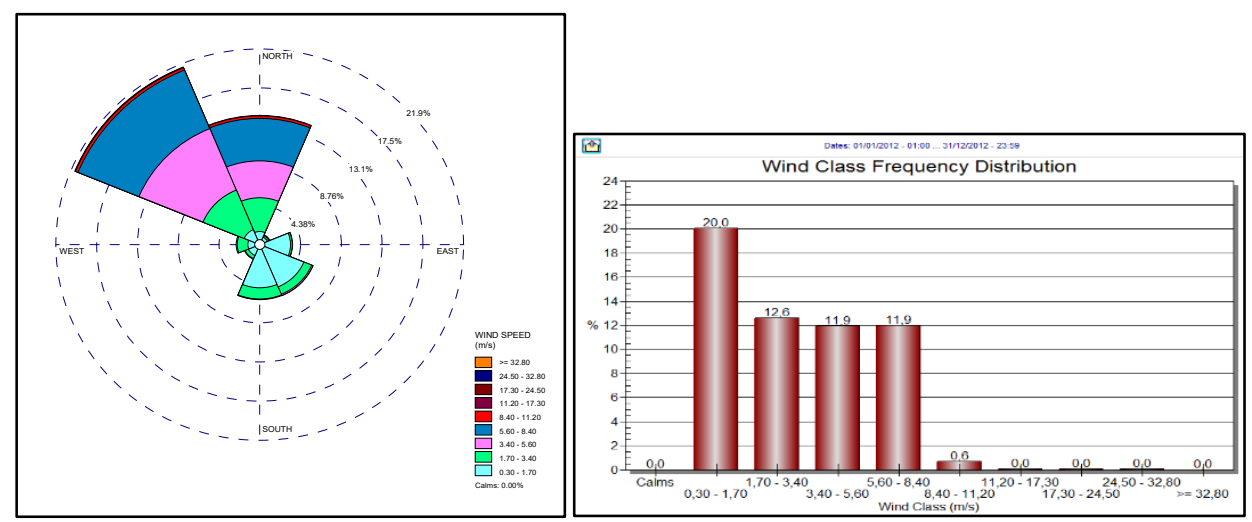

Fig. 3. Windrose and histogram 2012 

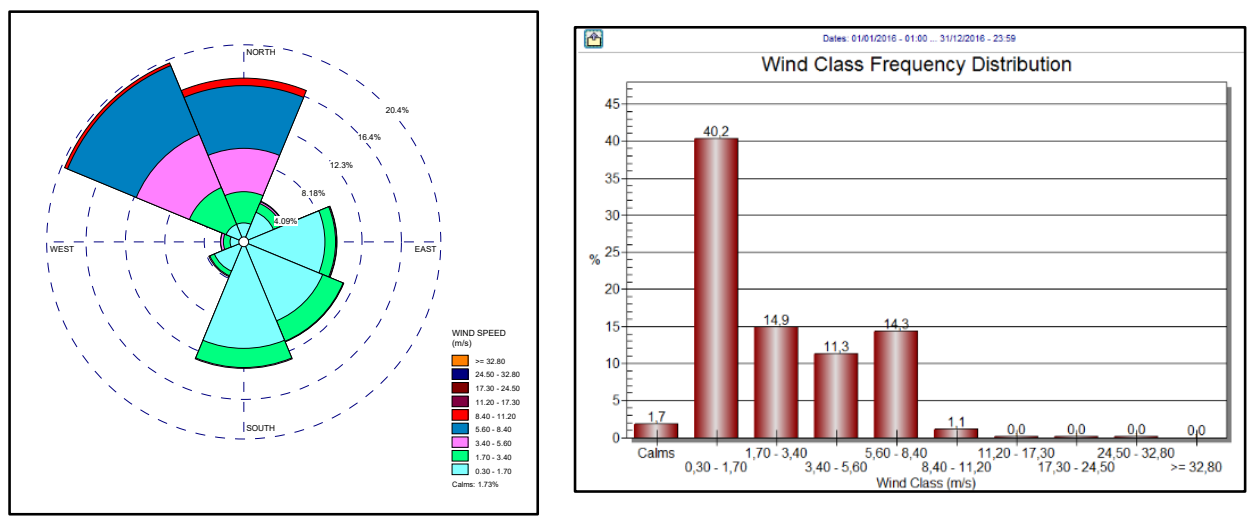

Fig. 4. Windrose and histogram 2016

dominant wind direction from 2012 to 2016 is in the northwest direction (NW).

Table 1. Maximum wind stress

\begin{tabular}{|c|c|c|c|c|c|c|c|c|c|c|}
\hline \multirow{2}{*}{ No } & \multirow{2}{*}{ Year } & North & $\begin{array}{c}\text { North } \\
\text { East }\end{array}$ & East & $\begin{array}{c}\text { South } \\
\text { East }\end{array}$ & South & $\begin{array}{c}\text { South } \\
\text { West }\end{array}$ & West & $\begin{array}{c}\text { North } \\
\text { West }\end{array}$ \\
\cline { 2 - 10 } & & $\mathbf{m} / \mathbf{s}$ & $\mathbf{m} / \mathbf{s}$ & $\mathbf{m} / \mathbf{s}$ & $\mathbf{m} / \mathbf{s}$ & $\mathbf{m} / \mathbf{s}$ & $\mathbf{m} / \mathbf{s}$ & $\mathbf{m} / \mathbf{s}$ & $\mathbf{m} / \mathbf{s}$ \\
\cline { 2 - 11 } & & \multicolumn{7}{|c|}{$\mathbf{U}_{\mathbf{A}}$} & \\
\hline 1 & 2012 & 16,02 & 14,85 & 8,13 & 8,97 & 15,44 & 8,13 & 7,41 & 35,57 \\
\hline 2 & 2013 & 35,57 & 20,67 & 28,50 & 9,65 & 5,93 & 7,41 & 43,81 & 34,11 \\
\hline 3 & 2014 & 34,11 & 13,65 & 37,39 & 40,66 & 5,93 & 5,93 & 8,13 & 20,10 \\
\hline 4 & 2015 & 37,39 & 10,99 & 13,03 & 6,68 & 6,68 & 5,93 & 17,28 & 23,16 \\
\hline 5 & 2016 & 14,25 & 9,65 & 28,50 & 20,67 & 6,68 & 7,41 & 46,30 & 14,25 \\
\hline
\end{tabular}

To determine the length of wave fetch, the author uses a map obtained from the google earth application as shown in the following figure. then drag the line from the research point to each island that is closest to the angle of every $6^{\circ}$.

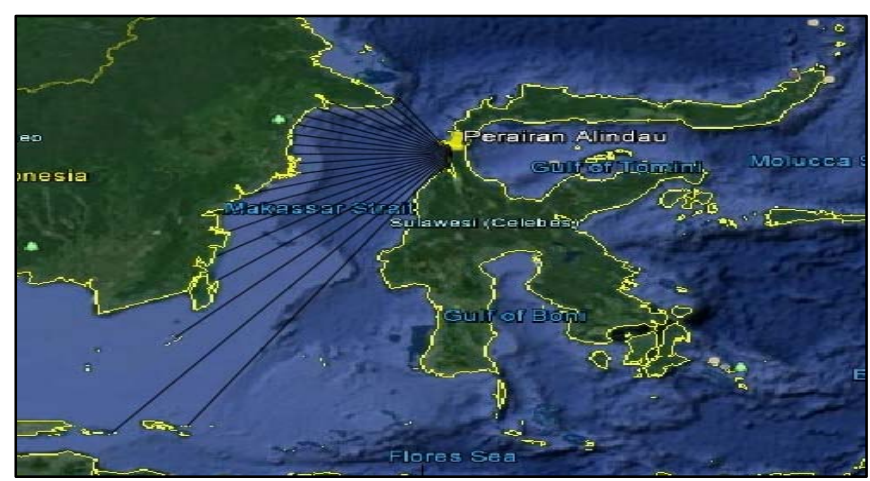

(Source: Google Earth)

Fig. 5. Alindau fetch 
Wave height affects the amount of power produced by OWC.

Table 2. Maximum wave height according to the wind direction

\begin{tabular}{|c|c|c|c|c|c|c|c|c|c|c|}
\hline \multirow{2}{*}{ No } & \multirow{2}{*}{ Year } & $\mathbf{N}$ & NE & E & SE & S & SW & W & NW \\
\cline { 3 - 10 } & & \multicolumn{9}{|c|}{ Hs(m) } \\
\hline 1 & 2012 & 1,27 & 1,15 & 0,52 & 0,59 & 1,21 & 0,52 & 0,46 & 3,56 \\
\hline 2 & 2013 & 3,56 & 1,77 & 2,68 & 0,65 & 0,34 & 0,46 & 4,65 & 3,37 \\
\hline 3 & 2014 & 3,37 & 1,03 & 3,79 & 4,22 & 0,34 & 0,34 & 0,52 & 1,70 \\
\hline 4 & 2015 & 3,79 & 0,77 & 0,97 & 0,40 & 0,40 & 0,34 & 1,40 & 2,05 \\
\hline 5 & 2016 & 1,09 & 0,65 & 2,68 & 1,77 & 0,40 & 0,46 & 4,99 & 1,09 \\
\hline
\end{tabular}

Table 3. Wave period

\begin{tabular}{|c|c|c|c|c|c|c|c|c|c|}
\hline \multirow{2}{*}{ No } & \multirow{2}{*}{ Year } & N & NE & E & SE & S & SW & W & NW \\
\cline { 3 - 10 } & & \multicolumn{9}{|c|}{ T(s) } \\
\hline 1 & 2012 & 4,00 & 3,81 & 2,56 & 2,73 & 3,90 & 2,56 & 2,41 & 6,70 \\
\hline 2 & 2013 & 6,70 & 4,72 & 5,81 & 2,87 & 2,08 & 2,41 & 7,65 & 6,52 \\
\hline 3 & 2014 & 6,52 & 3,60 & 6,91 & 7,30 & 2,08 & 2,08 & 2,56 & 4,63 \\
\hline 4 & 2015 & 6,91 & 3,12 & 3,49 & 2,25 & 2,25 & 2,08 & 4,20 & 5,08 \\
\hline 5 & 2016 & 3,71 & 2,87 & 5,81 & 4,72 & 2,25 & 2,41 & 7,93 & 3,71 \\
\hline
\end{tabular}

As in wave height, the wave period taken is only the largest one in each year.

Table 4. Height, period, radian and wind duration.

\begin{tabular}{|c|c|c|c|c|c|}
\hline No & Year & Hs (m) & T(s) & $\omega$ (rad/det) & t(det) \\
\hline 1 & 2012 & 3,56 & 6,70 & 0,94 & 1620,00 \\
\hline 2 & 2013 & 4,65 & 7,65 & 0,82 & 1500,00 \\
\hline 3 & 2014 & 4,22 & 7,30 & 0,86 & 1530,00 \\
\hline 4 & 2015 & 3,79 & 6,91 & 0,91 & 1560,00 \\
\hline 5 & 2016 & 4,99 & 7,93 & 0,79 & 1440,00 \\
\hline
\end{tabular}

Table 5. The amount of power generated by OWC for 5 years

\begin{tabular}{|c|c|c|c|c|c|c|c|c|}
\hline \multirow{2}{*}{ Year } & $\mathbf{U A}$ & $\mathbf{d} \boldsymbol{}$ & $\mathbf{P 2}$ & $\mathbf{E}$ & $\mathbf{P w}$ & $\begin{array}{c}\boldsymbol{\eta} \\
\text { OWC }\end{array}$ & $\begin{array}{c}\boldsymbol{\eta} \\
\mathbf{P L T} \\
\mathbf{G L}\end{array}$ & $\mathbf{P g}$ \\
\cline { 2 - 9 } & $\mathbf{m}$ & $\mathbf{r a d}$ & $\mathbf{P a}$ & $\mathbf{W a t t}$ & $\mathbf{W a t t}$ & $\mathbf{W a t t}$ & $\mathbf{W a t t}$ & Watt \\
\hline 2012 & 35.57 & -2.76 & 101038.96 & 256.34 & 777.89 & 32.95 & 23.8 & 18520.7 \\
\hline 2013 & 43.81 & -4.84 & 101011.75 & 42.50 & 1516.51 & 2.80 & 2.1 & 3070.5 \\
\hline 2014 & 40.66 & -8.93 & 101034.05 & 209.50 & 1194.52 & 17.54 & 12.8 & 15136.2 \\
\hline 2015 & 37.39 & 4.11 & 101010.15 & 26.37 & 912.86 & 2.89 & 2.1 & 1905.5 \\
\hline 2016 & 46.30 & -12.29 & 101043.33 & 300.83 & 1809.16 & 16.63 & 12.1 & 21735.1 \\
\hline
\end{tabular}


Tidal validation results in the form of tidal observation data for fifteen days with a reading interval of every one hour seen in Fig. 6.

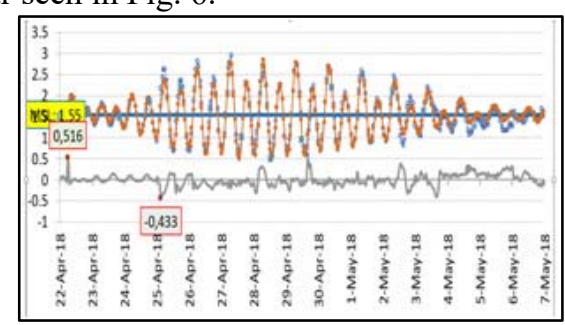

Fig 6. Alindau tides data

Table 6. Main components of Alindau tides

\begin{tabular}{|c|c|c|c|c|c|c|c|c|c|}
\hline No & Constituents & Symbol & Description & $\begin{array}{l}\text { Period } \\
\text { (hour) }\end{array}$ & $\begin{array}{c}\omega \\
\text { (rad/ } \\
\text { hour) }\end{array}$ & $\mathbf{A}$ & $\mathbf{B}$ & $\begin{array}{c}g^{\circ} \\
\text { phase }\end{array}$ & $\begin{array}{c}\text { H=Ampli } \\
\text { tude (m) }\end{array}$ \\
\hline 0. & $\begin{array}{l}\text { Avarage } \\
\text { water level }\end{array}$ & $Z_{0}$ & & - & - & & & & 1.9034 \\
\hline 1. & $\begin{array}{l}\text { Main solar } \\
\text { constituent }\end{array}$ & $M_{2}$ & \multirow{4}{*}{$\begin{array}{c}\text { Semi } \\
\text { diurnal }\end{array}$} & 12.4206 & $\begin{array}{c}0.505 \\
87\end{array}$ & $\begin{array}{c}0 . \\
40 \\
17\end{array}$ & $\begin{array}{l}0 . \\
04 \\
04\end{array}$ & $\begin{array}{c}5.743 \\
2^{\circ}\end{array}$ & 0,4037 \\
\hline 2. & $\begin{array}{l}\text { Main solar } \\
\text { constituent }\end{array}$ & $S_{2}$ & & 12.0000 & $\begin{array}{c}0.523 \\
60\end{array}$ & $\begin{array}{l}- \\
0 . \\
56 \\
67\end{array}$ & $\begin{array}{c}- \\
0 . \\
31 \\
19\end{array}$ & $\begin{array}{l}208.8 \\
300^{\circ}\end{array}$ & 0.6469 \\
\hline 3. & $\begin{array}{l}\text { Lunar } \\
\text { constituent, } \\
\text { due to Earth- } \\
\text { Moon } \\
\text { distance }\end{array}$ & $N_{2}$ & & 12.6582 & $\begin{array}{c}0.496 \\
37\end{array}$ & $\begin{array}{c}- \\
0 . \\
08 \\
74\end{array}$ & $\begin{array}{c}0 . \\
02 \\
42\end{array}$ & $\begin{array}{l}164.5 \\
393^{\circ}\end{array}$ & 0.0907 \\
\hline 4. & $\begin{array}{l}\text { Soli-lunar } \\
\text { constituent, } \\
\text { due to the } \\
\text { change of } \\
\text { declination }\end{array}$ & $K_{2}$ & & 11.9673 & $\begin{array}{c}0.525 \\
03\end{array}$ & $\begin{array}{l}0 . \\
51 \\
04\end{array}$ & $\begin{array}{l}0 . \\
53 \\
66\end{array}$ & $\begin{array}{c}46.43 \\
68^{\circ}\end{array}$ & 0.7406 \\
\hline 5. & $\begin{array}{l}\text { Soli-lunar } \\
\text { constituent }\end{array}$ & $K_{1}$ & \multirow{3}{*}{ diurnal } & 23.9346 & $\begin{array}{c}0.262 \\
51\end{array}$ & $\begin{array}{c}- \\
0 . \\
34 \\
82\end{array}$ & $\begin{array}{c}- \\
0 . \\
31 \\
90\end{array}$ & $\begin{array}{c}222.4 \\
960^{\circ}\end{array}$ & 0.4723 \\
\hline 6. & $\begin{array}{l}\text { Main lunar } \\
\text { constituent }\end{array}$ & $O_{1}$ & & 25.8194 & $\begin{array}{c}0.243 \\
35\end{array}$ & $\begin{array}{c}- \\
0 . \\
11 \\
66\end{array}$ & $\begin{array}{l}0 . \\
01 \\
95\end{array}$ & $\begin{array}{l}170.5 \\
880^{\circ}\end{array}$ & 0.1183 \\
\hline 7 & $\begin{array}{l}\text { Main lunar } \\
\text { constituent }\end{array}$ & $P_{1}$ & & 24.0658 & $\begin{array}{c}0.261 \\
08\end{array}$ & $\begin{array}{c}0 . \\
20 \\
23\end{array}$ & $\begin{array}{l}0 . \\
29 \\
53\end{array}$ & $\begin{array}{c}55.58 \\
80^{\circ}\end{array}$ & 0.3579 \\
\hline 8 & $\begin{array}{l}\text { Main lunar } \\
\text { constituent }\end{array}$ & $M_{4}$ & \multirow{2}{*}{ quarterly } & 6.2103 & $\begin{array}{c}1.011 \\
74\end{array}$ & $\begin{array}{c}0 . \\
00 \\
37\end{array}$ & $\begin{array}{c}0 . \\
00 \\
46\end{array}$ & $\begin{array}{c}50.61 \\
95^{\circ}\end{array}$ & 0.0059 \\
\hline 9 & $\begin{array}{l}\text { Soli-lunar } \\
\text { constituent }\end{array}$ & $M S_{4}$ & & 6.1033 & $\begin{array}{c}1.029 \\
47\end{array}$ & $\begin{array}{c}0 . \\
00 \\
48\end{array}$ & $\begin{array}{l}0 . \\
00 \\
65\end{array}$ & $\begin{array}{c}53.18 \\
12^{\circ}\end{array}$ & 0.0081 \\
\hline
\end{tabular}


The method used in tidal data analysis is the Least Square method that is calculating the tidal harmonic constants consisting of the mean sea level, amplitude and phase of the nine main tidal components $\left(M_{2}, S_{2}, N_{2}, K_{2}, O_{2}, M_{4}, M S_{4}, K_{2}\right.$, and $\left.P_{1}\right)$. The results of the Mean Sea Level (MSL) calculation and the nine harmonic constants are used to find the Highest High-Water Level (HHWL) and Lowest Low Water Level (LLWL) values. From the main components of these tides, tidal characteristics can be determined, that is by using Formzahl (F) numbers.

Table 7. Important elevation tides of Alindau beach

\begin{tabular}{|c|c|c|c|c|}
\hline No & Position & $\begin{array}{c}\text { MSL } \\
\text { prediction }\end{array}$ & MSL & Range \\
\hline 1 & HHWL & 3,55 & 1,90 & 1,64 \\
\hline 2 & MHWS & 2,49 & 1,90 & 0,59 \\
\hline 3 & MHWL & 2,26 & 1,90 & 0,35 \\
\hline 4 & MSL & 1,90 & 1,90 & 0,00 \\
\hline 5 & MLWL & 1,55 & 1,90 & $-0,35$ \\
\hline 6 & MLWS & 1,31 & 1,90 & $-0,59$ \\
\hline 7 & LLWL & 0,26 & 1,90 & $-1,64$ \\
\hline
\end{tabular}

Based on data from observations that the tides peak at the Alindau location are around $3,433 \mathrm{~cm}$.

From the results of measurements of marine bathymetry, for the placement criteria for PLTGL OWC tools is to pay attention to the results of the tidal research, waves, and coastal conditions in Kaliburu Village as for this time according to the survey results and the results of tidal data processing, the highest tide is at +1.64 from the neutral sea level line and the lowest ebb is at -1.64 from the neutral sea level. So, based on this data the PLTGL OWC device placement plan is in the depth of sea water $20 \mathrm{~m}$ above sea level by observing based on coastal conditions that a depth of $20 \mathrm{~m}$ is $100 \mathrm{~m}$ from the coastline.

\section{Conclusion}

Maximum wave height forecast per year obtained using the Wilson Method, in 2012 maximum wave height of $3.56 \mathrm{~m}, 2013$ about $4.65 \mathrm{~m}, 2014$ about $4.22 \mathrm{~m}, 2015$ about 3.79 $\mathrm{m}$ and in 2016 a maximum wave height about $4.99 \mathrm{~m}$. From the results, we move to calculate the amount of power generated from the wave height. As for the results obtained is a wave height of $3.56 \mathrm{~m}$ generates a power of 18520.7 watts, $4.65 \mathrm{~m}$ generates a power of 3070.5 watts, $4.22 \mathrm{~m}$ generates a power of 15136.2 watts, $3.79 \mathrm{~m}$ generates power of 1905.5 watts and $4.99 \mathrm{~m}$ wave height generates power of 21735.1 watts. It shows the potential that can be exploited from the wave energy in Alindau Village. By applying this technology, it is estimated that it can coverage electricity needs of dozens of households in the Alindau village.

With the development of this research, we hope that further comparisons of wave height calculation methods can be made so that the results can be more accurate and to compare the wind data used in this study so that the data used can obtain maximum results. 


\section{References}

1. World's first commercial wave power station activated in Scotland. Archived from the original (2018)

2. Seabased AB wave energy technology. Archived from the original (2017)

3. Power Buoy Technology-Ocean Power Technologies. Archived from the original (2017)

4. Perth Wave Energy Project-Carnegie's CETO Wave Energy technology. Archived from the original (2017)

5. Matthew L, Wayback Machine, Wald. Underwater Cable an Alternative to Electrical Towers New York Times (2010)

6. Extracting Energy from Ocean Waves. Archived from the original (2015)

7. Adi, Chaplin, Deborah, Greaves, Kurniawan, John. Wave energy devices with compressible volumes. Proceedings of the Royal Society of London A: Mathematical, Physical and Engineering Sciences (2014)

8. Tethys. Archived from the original (2014)

9. Ocean Wave Energy / BOEM. www.boem.gov (2019)

10. Andrew, Sendy. How has the price and efficiency of solar panels changed over time? (2018)

11. Como, Steve et al. Ocean Wave Energy Harvesting-Off-Shore Overtopping Design (2015)

12. Gallucci, M. At last, wave energy tech plugs into the grid (2019)

13. Seabased Closes Production Facility in Sweden. Marine energy (2019)

14. Giassi, Göteman, Marianna, Malin. Layout design of wave energy parks by a genetic algorithm". Ocean Engineering (2018)

15. Scott Macnab. Government's $£ 200 m$ wave energy plan undermined by failures (2017) 